\title{
Characterization and comparative sequence analyzes of GABA receptor gene in Asian main malaria mosquito, Anopheles stephensi
}

\author{
Saber Gholizadeh, Ameneh Karimi, Nooshin Bayat, Navid Dinparast Djadid*, Sedigheh Zakeri \\ From Parasite to Prevention: Advances in the understanding of malaria \\ Edinburgh, UK. 20-22 October 2010
}

\section{Background}

The mutations occurring in receptor genes of Gama Amino Butyric Acid (GABA) play important roles in resistance to cychlodien insecticides in mosquitoes. Here we report the sequence analysis of the $R d l$ gene from Asian main malaria mosquito, Anopheles stephensi, using specific primers in the polymerase chain reaction.

\section{Method and results}

Mosquitoes were collected from Fars, Hormozgan, Kerman and Sistan \& Baluchistan provinces of Iran. A 256bp sequence of GABA receptor showed $99-100 \%$ similarity between An. stephensi populations in Iran. Gas chromatography count was $41.63 \%$ with 86 amino acid sequences. Alteration in amino acid sequence that has been found in An. stephensi populations will be discussed in detail, in comparison with An. gambiae.

\section{Conclusion}

Understanding of molecular structure of resistance can provide baseline data to evaluate population genetics of pesticide resistance, which will be applicable in operational vector control measures and sterile insect technique.

Published: 20 October 2010

\section{References}

1. Thompson M, Shotkoski F, french-Constant R: Cloning and sequencing of the cyclodiene insecticide resistance gene from the yellow fever mosquito Aedes aegypti. Conservation of the gene and resistance associated mutation with Drosophila. FEBS Lett 1993, 325:187-90.

Insectarium, Malaria and Vector Research Group (MVRG), Biotechnology Research Center (BRC), Pasteur Institute of Iran (PII), Pasteur Avenue, PO BOX 1316943551, Tehran, Iran
2. Buckingham SD, Biggin PC, Sattelle BM, Brown LA, Sattelle DB: Insect GABA receptors: splicing, editing, and targeting by antiparasitics and insecticides. Mol Pharmacol 2005, 68:942-51.

doi:10.1186/1475-2875-9-S2-015

Cite this article as: Gholizadeh et al:: Characterization and comparative sequence analyzes of GABA receptor gene in Asian main malaria mosquito, Anopheles stephensi. Malaria Journal 2010 9(Suppl 2):015.
Submit your next manuscript to BioMed Central and take full advantage of:

- Convenient online submission

- Thorough peer review

- No space constraints or color figure charges

- Immediate publication on acceptance

- Inclusion in PubMed, CAS, Scopus and Google Scholar

- Research which is freely available for redistribution

Submit your manuscript at www.biomedcentral.com/submit
( ) Biomed Central 